\title{
Food and Feeding Habits of Wedge Clam (Donax cuneatus) Off Thoothukudi, Gulf of Mannar, India
}

\author{
S. Takar, P. Jawahar, U.R. Gurjar', S.D. Kingston, \\ N. Neethiselvan, J.J. Pereira, I. Jagadis²
}

10.18805/IJAR.B-4534

\begin{abstract}
Background: Bivalves are benthic animals existing in coastal habitats, particularly mudflats and tidal. Because of their availability, rich protein content and cheaper cost, they contribute a major portion of the small-scale fishery resource worldwide. Limited information has been available on the food-feeding and habitat structures of bivalves along Indian waters. Therefore, the present investigation was carried out to know the food-feeding and habitat preferred by wedge clam, Donax cuneatus off Thoothukudi, Gulf of Mannar, India.

Methods: Soil, water and wedge clam samples were collected from the selected site from September 2019 to March 2021 and soil texture, water quality parameters and gut contents were analyzed at the laboratory.

Result: During the study period, salinity, water temperature, $\mathrm{pH}$ and dissolved oxygen (DO) were in the range from 31-37\%, $24-$ $28^{\circ} \mathrm{C}, 7.7-8.7$ and 4.1-5.8 $\mathrm{mg} / \mathrm{l}$, respectively. Wedge clams were mainly observed at sandy beaches up to $10 \mathrm{~cm}$ in depth. Donax cuneatus mainly feeds on detritus $(65 \%)$, followed by phytoplankton $(31 \%)$ and zooplankton $(4 \%)$. Hence, the diverse fluctuation of food particles, season-specific food and feeding biology and local environmental conditions at the studied region might be the responsible features for the availability of Donax cuneatus.
\end{abstract}

Key words: Feeding ecology, Gulf of mannar, Habitat, Plankton, Wedge clam.

\section{INTRODUCTION}

Within the Phylum Mollusca, Bivalvia is the second-largest taxonomic class with about 10,000 existing species documented worldwide (Rahman et al. 2015). The diversity of bivalves includes 101 families and 1,380 genera with 9,620 species (Huber, 2015). Globally, annual total marine bivalve production is more than 15 million tons, with Asia alone producing more than $85 \%$ (FAO, 2017; Wijsman et al. 2019). Bivalves are mainly suspension and deposit-feeders in nature (Desai et al. 2020; Maloy et al. 2013), so they can modify, maintain and build complete habitats (Dame, 1996). Bivalve serves a critical role in benthic-pelagic coupling and nutrient recycling processes in the coastal ecosystem (Dame, 1996). These organisms are attached to the solid substratum or even bored in the rigid substrates (Gosling, 2003). They are discriminating particle feeders having wellbuilt mechanisms for particle selection (Ward and Shumway, 2004). In, bivalve filtration and feeding processes mainly depend on the structure of gill and concentration of particles in the adjacent waters (Jorgensen, 1996); food-feeding depends on the surface and shape of the particles (Bougrier et al. 1997).

Benthic communities might be experiencing different responses based on the food availability and competition presumably among the consumers for limited food resources (Campanya-Llovet et al. 2017). They are important mediators to transfer energy from primary producers to the consumers or the next trophic level (Wang et al. 2015). Bivalves are keystone species that monitor the phytoplankton by grazing, destroying bio-indicators for marine habitats as a top-down
Fisheries College and Research Institute, Tamil Nadu Dr. J. Jayalalithaa Fisheries University, Thoothukudi-628 008, Tamil Nadu, India.

1ICAR- Central Institute of Fisheries Education, Mumbai-400 061, Maharashtra, India.

${ }^{2}$ CAR-Central Marine Fisheries Research Institute, Regional Centre, Thoothukudi-628 008, Tamil Nadu, India.

Corresponding Author: S. Takar, Fisheries College and Research Institute, Tamil Nadu Dr. J. Jayalalithaa Fisheries University, Thoothukudi-628 008, Tamil Nadu, India.

Email: takarsuman42@gmail.com

How to cite this article: Takar, S., Jawahar, P., Gurjar, U.R., Kingston, S.D., Neethiselvan, N., Pereira, J.J. and Jagadis, I. (2021). Food and Feeding Habits of Wedge Clam (Donax cuneatus) Off Thoothukudi, Gulf of Mannar, India. Indian Journal of Animal Research. DOI: 10.18805/IJAR.B-4534.

Submitted: 20-05-2021 Accepted: 26-07-2021 Online: 21-08-2021

and bio-deposition of nutrients as a bottom-up mechanism in the aquatic ecosystem (Newell, 2004; Pandey et al. 2018; Khudhur and Shekha, 2019). The bivalves family Donacidae, is widely distributed in the Indo-West Pacific, from East Africa, including Mauritius, Madagascar and Reunion Islands, to New Caledonia, South to New South Wales and North to Southern Japan and dominant in the tropical and temperate region where they are exposed to sandy beaches (Ansell, 1983; FAO, 1998). Donacids are filter feeders in nature (Singh, 2017) and they play a vital role in the benthicpelagic food web (Dame, 1996). They are also subject to 
predation by varied varieties of invertebrates, birds, fish and mammals (Loesch, 1957).

The global human population is continuously growing up and natural resources are limited; hence, bivalves can be an alternative source to provide a nutritional diet for humans. In Asia, millions of people using bivalves as inexpensive and affordable healthy food items rich in amino acids, essential fatty acids, essential minerals and vitamins (Joy and Chakraborty, 2017). At the same time, food is a major substance for any organism in the ecosystem; therefore, it is essential to know the feeding nature of particular species. From Indian waters, limited information is available on the food, feeding habits and habitat structures of Donax cuneatus. Therefore, the current study was conducted to know the food and feeding habits of wedge clam from the Thoothukudi, Gulf of Mannar, India.

\section{MATERIALS AND METHODS}

During the period of September 2019 to March 2021, the wedge clam samples were collected from Tuticorin, Harbour beach (Latitude- $8^{\circ} 44^{\prime} 34.53^{\prime \prime} \mathrm{N}$ and Longitude- 78 $10^{\prime} 2.96^{\prime \prime} \mathrm{E}$ ), situated in the southern part of Tamil Nadu. Monthly, around thirty individuals of wedge clams were handpicked during the high tide and collected specimens were brought to the fisheries biology laboratory of the institute for further gut content analysis (Ma and Mukai, 2009).

A total of 390 specimens of $D$. cuneatus in the length range of $11-23 \mathrm{~mm}$ and weight range of $0.6-2.12 \mathrm{~g}$ were examined for food and feeding study. Samples were incised through a knife and scalpel and the gut was removed from meat tissues using a sharp blade. The guts were emptied into a test tube mixed with one $\mathrm{ml}$ of distilled water. The same was poured onto Sedgwick-Rafter (S-R) cell and examined under a binocular photomicroscope. The food items were identified up to the genera level using the taxonomic keys given by Santhanam et al. (1987) and Mitra et al. (2004). Quantitative and qualitative analysis of gut contents were carried out using the numerical method (Biswas, 1993). The relative volume of each item was calculated as per the point method and points are allotted based on the size of the food item and relative dominance in the gut (Gurjar et al. 2017). For habitat characteristics, sediment samples were collected from sampling locations and brought to the laboratory for further analysis. For determining the composition and texture of the soil, samples were analyzed as per the method given by Bragadeeswaran et al. (2007). The monthly salinity (hand-held refractometer ATAGO S/Mill-E), water temperature (calibrated mercury thermometer), $\mathrm{pH}$ (microprocessor $\mathrm{pH}$ meter) were measured and dissolved oxygen (DO) was estimated by standard methods of APHA (2012).

\section{RESULTS AND DISCUSSION}

The present study indicated that primarily wedge clam preferred to inhabiting sandy beaches where more than 80 percent of soil texture was sand and the remaining were muddy and silty textures. Samples of wedge clam were found up to $10 \mathrm{~cm}$ depth, but more than $65 \%$ of specimens were observed from $2-5 \mathrm{~cm}$ during the spring tide. Salinity, water temperature, $\mathrm{pH}$ and dissolved oxygen (DO) were recorded in the range from $31-37 \%, 24-28^{\circ} \mathrm{C}, 7.7-8.7$ and $4.1-5.8 \mathrm{mg} /$, respectively. In the present study it has been observed that wedge calm is a quick burrower in the sandy beaches and lives under the surface of wave-swept parts of intertidal areas along Harbour beach of Thoothukudi coast. Earlier authors also reported that wedge clams were mainly present in sandy beaches along intertidal zone (Ansell, 1983; Tan and Low, 2013). Some bivalve species live under the buried condition in soft or sandy bottoms, whereas others are attached on or even bored in the hard substratum (Gosling, 2003). In the present study, $D$. cuneatus was mainly observed during high tide, which might be due to favourable conditions to get their food items. During high tide, they become more active and move towards the surface for feeding. McLusky and Stirling (1975) also observed that the feeding of Donax species depends on wave action and water movement. Salas and Hergueta (1990) also reported that Donax species lived in wave-beaten areas and high-energy environments. The abundance of $D$. cuneatus was affected by the result of various factors such as effluent and industrial discharge into coastal areas of the southeast coast of India (Hussain et al. 2010).

\section{Food composition}

In the present study, different food items such as phytoplankton (Amphora spp. Bacillaria paxillifera, Coscinodiscus spp. Hemidiscus cuneiformis, Navicula spp. Pinnularia spp. Pleurosigma spp. Rhizosolenia spp. Skeletonema spp. Schroederella spp. Thlassionema spp. Thalassiosira spp. and Trichodesmium spp), zooplankton (copepods, eggs, foraminifera, tintinnids) and detritus were recorded from the gut content of wedge clam (Table 1). Xu and Yang (2007) stated that phytoplankton is the main food source for the various organisms present in the intertidal areas. Several studies revealed that other than phytoplankton, supplementary food sources such as detritus, bacteria and zooplankton are also important for their growth and survival (Lehane and Davenport, 2002; Prato et al. 2010). Wang et al. (2015) stated that bivalves feeding could vary on the availability of food items in the surrounding environment and species-specific feeding strategies.

Group-wise contribution of food items has been dominated by detritus (65\%), followed by phytoplankton (31\%) and zooplankton (4\%) (Fig 1). Bacillariophyceae was dominantly observed among phytoplankton, while copepods were recorded as the main food items among zooplankton. The contribution of detritus in the bivalve diet is more important when the availability of the phytoplankton was very less to satisfy the energy needs of bivalves (Langdon and Newell, 1990).

\section{Monthly variation in food items}

\section{Phytoplankton}

In the present study, among phytoplankton, diatoms were 
abundantly recorded from the gut contents of wedge clams during the entire study period (Table 1). Malviya et al. (2016) reported that diatoms are the most important ecologically phytoplankton groups, contributing about $20 \%$ of primary productivity worldwide. From January to March (postmonsoon), a higher abundance of phytoplankton such as Bacillaria spp. Coscinodiscus spp. and Navicula spp. were observed in the gut of wedge clam, which might be due to higher diversity and abundance of phytoplankton in the postmonsoon season Thoothukudi, Southeast Coast of India (Velmurgan et al. 2014).

According to earlier studies, phytoplankton was known as a primary and important food item for bivalves (Gosling, 2003; Xu and Yang, 2007). In the present study, less number of phytoplankton was observed during October to December as monsoon season (Fig 2) might be due to the low intensity of light and some other abiotic factors responsible for affecting plankton production (Bragadeeswaran et al. 2007). Subsequently, a higher percentage of detritus was observed due to a lower abundance of plankton in surrounding waters and heavy rain during this period which leads to more influx of sediments through surface runoff waters. Bragadeeswaran et al. (2007) reported that the composition of sand in sediment was higher during the monsoon season. Wang et al. (2015) have been observed that phytoplankton abundance decline as a consequence of bivalve grazing. Arapov et al. (2010) observed that the concentration of phytoplankton communities depends on the surrounding water. The accumulation of food items in filter-feeders would presumably reflect their concentrations in water (Zuykov et al. 2013).

\section{Zooplankton}

In the present study, the gut matrix of wedge clam has shown monthly variations among different zooplanktons such as copepods, foraminifera, eggs and tintinnids (Table 1 ). Lehane and Davenport (2002) recorded that bivalves could ingest various zooplankton as copepods, barnacle cyprids, ostracods, bivalve larvae, crustacean nauplii, amphipods,

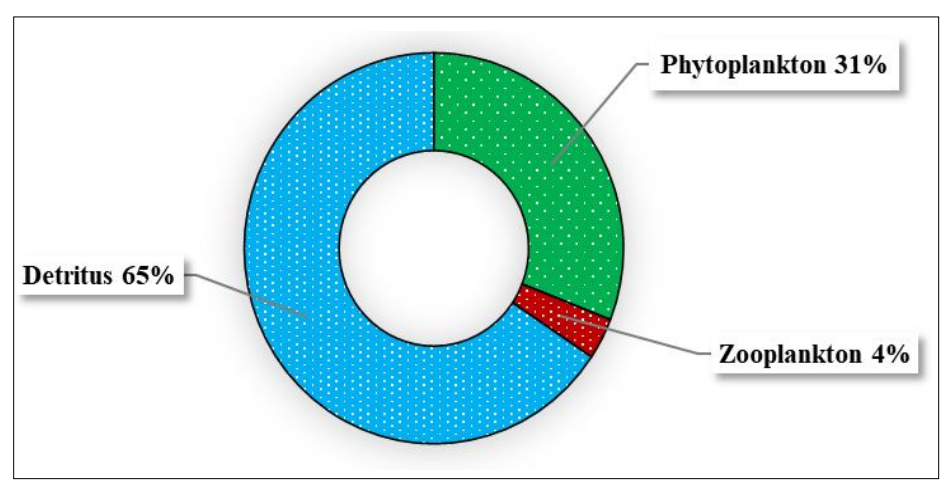

Fig 1: The overall contribution of food items in the gut of wedge clam, Donax cuneatus.

Table: 1 Percentage-wise food items recorded in the guts of wedge clam, Donax cuneatus.

\begin{tabular}{lcccccccccccc}
\hline Food items & Sep- & Oct- & Nov- & Dec- & Jan- & Feb- & Mar- & Oct- & Nov- & Dec- & Jan- & Feb- \\
& 19 & 19 & 19 & 19 & 20 & 20 & 20 & 20 & 20 & 20 & 21 & 21 \\
21
\end{tabular}




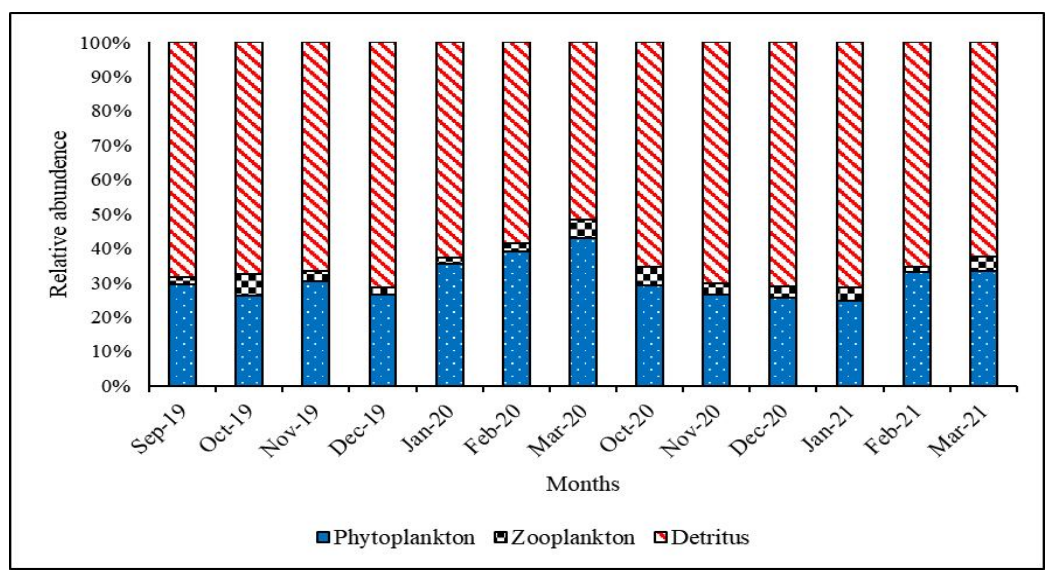

Fig 2: Bar diagram showing the monthly composition of different food groups in the gut of wedge clam, Donax cuneatus.

unidentified eggs, cladocerans, euphausiacea, hydromedusae and foraminifera. In the current study, zooplankton was contributed only $4 \%$ of total food items in the gut of studied samples, revealing that wedge clam has less preferred zooplankton than phytoplankton. Bivalve could ingest zooplankton but selectively consumed smaller categories (Lehane and Davenport, 2002).

\section{Detritus}

The detritus as organic matter were dominantly observed throughout the study period. In contrast, a higher contribution (more than $70 \%$ ) was observed in the monsoon season from October to December (Fig 2), which could be due to the influx of sediments resulted from heavy rains. Davenport et al. (2011) studied the food-feeding of Pinna nobilis and observed that volume-wise detritus contributed more than $95 \%$ of total food items. Langdon and Newell (1990) revealed that the contribution of detritus in the bivalve diet is much important when the phytoplankton abundance is very low to fulfill the required energy for the bivalve. In the present investigations, it has been reported that detritus contributed more than other food items in wedge clam, which could be due to the species which preferred sandy areas for their growth and development. Along sandy beach, food webs are primarily consisted by dissolved organic matter, carrion, wrack (stranded algae, partially fragmented leaves and sea grasses), fungi and bacteria living in the spaces between sand particles or attached to the surface of the grains, (McLachlan and Brown, 2006). The sediment texture plays a vital role in the feeding ecology and biology for suspension feeders because they collect their organic food particles (deposit faces and pseudo-faces) from the water column and sediment surface (Graf and Rosenberg, 1997; Chowdhury et al. 2019).

\section{CONCLUSION}

Wedge clams were mainly observed at sandy beaches up to $10 \mathrm{~cm}$ in depth in the present study and feeds on detritus, followed by phytoplankton and zooplankton. Thus, the diverse change in food particles, season-specific feeding biology and environmental conditions at the studied region might be the responsible factors for the availability of Donax cuneatus. This species is also having a lot of potential for culture which can not only provide low cost protein for nutritional security but can also provide livelihood to small and marginal farmers. However, the success of bivalve culture is dependent on water quality parameters and the availability of foods in surrounding environments. More systematic studies may be attempted for stage wise preference of feed, seed availability, habitat suitability, water quality preference etc.

\section{ACKNOWLEDGEMENT}

The authors are gratified to Dr. J. Jayalalithaa Fisheries University, Tamil Nadu, for the necessary support and encouragement.

\section{REFERENCES}

Ansell, A.D. (1983). The Biology of the Genus Donax. In: Sandy Beaches as Ecosystems, Springer, Dordrecht. 19: 607-635.

APHA (2012). Standard Methods for the Examination of Water and Wastewater. Washington, D.C. pp. 22.

Arapov, J., Ezgeta-Balic, D., Peharda, M. and Nincevic Gladan, Z. (2010). Bivalve feeding-how and what they eat? Croatian Journal of Fisheries. 68: 105-116.

Biswas, S.P. (1993). Manual of Methods in Fish Biology. South Asian Publishers Private Limited, Delhi. pp. 65-91.

Bougrier, S., Hawkins, A.J.S. and Heral, M. (1997). Preingestive selection of different microalgal mixtures in Crassostrea gigas and Mytilus edulis, analysed by flow cytometry. Aquaculture. 150: 123-134.

Bragadeeswaran, S., Rajasegar, M., Srinivasan, M. and Rajan, U.K. (2007). Sediment texture and nutrients of Arasalar estuary, Karaikkal, south-east coast of India. Journal of Environmental Biology. 28: 237-240.

Campanya-Llovet, N., Snelgrove, P.V. and Parrish, C.C. (2017). Rethinking the importance of food quality in marine benthic food webs. Progress in Oceanography. 156: 240-251. 
Chowdhury, M.S.N., Wijsman, J.W., Hossain, M.S., Ysebaert, T. and Smaal, A.C. (2019). A verified habitat suitability model for the intertidal rock oyster, Saccostrea cucullata. PloS one. 14: e0217688.

Dame, R. (1996). Ecology of Marine Bivalves: An ecosystem approach. Boca Raton: CRC press, Florida. pp. 284.

Davenport, J., Ezgeta-Balic, D., Peharda, M., Skejic, S., NincevicGladan, Z. and Matijevic, S. (2011). Size-differential feeding in Pinna nobilis L. (Mollusca: Bivalvia): Exploitation of detritus, phytoplankton and zooplankton. Estuarine, Coastal and Shelf Science. 92: 246-254.

Desai, D.V., Gardade, L., Khandeparker, L. and Anil, A.C. (2020). Habitat characteristics mediated partitioning of economically important bivalves in a tropical monsoon-influenced estuary. Environmental Science and Pollution Research. 27: 29303-29326.

FAO (1998). The Living Marine Resources of the Western Central Pacific: Seaweeds, Corals, Bivalves and Gastropods. Food and Agriculture Organisation of the United Nations, Rome.

FAO (2017). FAO Yearbook. Fishery and Aquaculture Statistics. 2015. Food and Agriculture Organisation of the United Nations Report. pp. 78.

Gosling, E. (2003). Bivalve growth. Bivalve molluscs: Biology Ecology and Culture. In: Fishing News Books. Blackwell Publishing, Oxford. pp. 169-200.

Graf, G. and Rosenberg, R. (1997). Bioresuspension and biodeposition: A review. Journal of Marine Systems. 11: 269-278.

Gurjar, U.R., Sawant, M.S., Pawar, R.A., Nirmale, V.H., Pawase, A.S. and Takar, S. (2017). A study on food and feeding habits of white sardine, Escualosa thoracata (valenciennes, 1847) from the Ratnagiri coast, Maharashtra. Journal of Experimental Zoology, India. 20: 755-762.

Huber, M. (2015). Compendium of bivalves 2. A full-color guide to the remaining seven families. A systematic listing of $8^{\prime} 500$ bivalve species and 10'500 synonyms. Hackenheim: Conch Books. pp. 907.

Hussain, K.J., Mohanty, A.K., Satpathy, K.K. and Prasad, M.V.R. (2010). Abundance pattern of wedge clam Donax cuneatus (L.) in different spatial scale in the vicinity of a coastal nuclear power plant. Environmental monitoring and assessment. 163: 185-194.

Jorgensen, C.B. (1996). Bivalve filter feeding revisited. Marine Ecology Progress Series. 142: 287-302.

Joy, M. and Chakraborty, K. (2017). Nutritional qualities of the lowvalue bivalve mollusks Paphia malabarica and Villorita cyprinoides at the estuarine waters of the southwestern coast of India. Journal of Aquatic Food Product Technology. 26: $54-70$.

Khudhur, S.M. and Shekha, Y.A. (2019). Histopathological and Biochemical Biomarker Response of Mussel, Unio pictorum, to Carbamate Pesticide Carbaryl: A Laboratory Study. Indian Journal of Animal Research. 1-5.

Langdon, C.J. and Newell, R.I. (1990). Utilization of detritus and bacteria as food sources by two bivalve suspensionfeeders, the oyster Crassostrea virginica and the mussel Geukensia demissa. Marine Ecology Progress Series. pp. 299-310.
Lehane, C. and Davenport, J. (2002). Ingestion of mesozooplankton by three species of bivalve; Mytilus edulis, Cerastoderma edule and Aequipecten opercularis. Journal of the Marine Biological Association of the U.K. 82: 615-619.

Loesch, H.C. (1957). Studies on the ecology of two species of Donax on Mustang Island, Texas. Ph.D. Thesis, Marine Science University, Texas, Brazos.

Ma, R.K. and Mukai, H. (2009). Food sources of the oyster (Crassostrea gigas) and the clam (Ruditapes philippinarum) in the Akkeshi-ko estuary. Plankton and Benthos Research. 4: 104-114.

McLachlan, A. and Brown, A.C. (2006). The ecology of sandy shores. Academic, Burlington.

Maloy, A.P., Nelle, P., Culloty, S.C., Slater, J.W. and Harrod, C. (2013). Identifying trophic variation in a marine suspension feeder: DNA-and stable isotope-based dietary analysis in Mytilus spp. Marine Biology. 160: 479-490.

Malviya, S., Scalco, E., Audic, S., Vincent, F., Veluchamy, A., Poulain, J., Wincker, P., ludicone, D., de Vargas, C., Bittner, L. and Zingone, A. (2016). Insights into global diatom distribution and diversity in the world's ocean. Proceedings of the National Academy of Sciences. 113: 1516-1525.

McLusky, D. and Stirling, A. (1975). The oxygen consumption and feeding of Donax incarnatus and Donax spiculum from tropical beaches. Comparative Biochemistry and Physiology Part A: Physiology. 51: 943-947.

Mitra, A., Banerjee, K. and Gangopadhyay, A. (2004). Introduction to marine plankton. Daya Publishing House.

Newell, R.I.E. (2004). Ecosystem influence of natural and cultivated populations of suspension-feeding bivalve molluscs: A review. Journal of Shellfish Research. 23: 51-61.

Pandey, A., Singh, A., Holeyappa, S.A. and Kaur, H. (2018). Enzymatic and antioxidant response of Lamellidens marginalis exposed to mercuric chloride. Indian Journal of Animal Research. 52: 658-663.

Prato, E., Danieli, A., Maffia, M. and Biandolino, F. (2010). Lipid and fatty acid compositions of Mytilus galloprovincialis cultured in the Mar Grande of Taranto (Southern Italy): feeding strategies and trophic relationships. Zoology Studies. 49: 211-219.

Rahman, M.A., Parvej, M.R., Rashid, M.H. and Hoq, M.E. (2015). Availability of pearl producing marine bivalves in southeastern coast of Bangladesh and culture potentialities. Journal of Fisheries. 3: 293-296.

Salas, C. and Hergueta, E. (1990). The functional morphology of the alimentary canal of Donax venustus Poli and $D$. semistriatus Poli. The Bivalvia. In: [Morton, B. (Ed.)], Proceedings of a Memorial Symposium in Honour of Sir Charles Maurice Yonge (1899-1986). Hong Kong University Press, Hong Kong. Pp. 213-222.

Santhanam, R. (1987). Phytoplankton of the Indian seas. Daya Publishing House. Delhi. pp. 127.

Singh, Y.T. (2017). Status of population dynamics of the Asian wedge clam, Donax scortum (Bivalvia: Donacidae): A first report from Asia. Journal of the Marine Biological Association of the United Kingdom. 97: 1635.

Tan, S.K. and Low, M.E.Y. (2013). Singapore Mollusca: 3. The family Donacidae (Bivalvia: Veneroida: Tellinoidea). Nature in Singapore. 6: 257-263. 
Velmurgan, P., Srinivasan, A., Athithan, A., Padmavathy, P., Manimegalai, D. and Anand, T. (2014). Diversity and seasonal variations of plankton in coastal waters receiving salt pan effluents off Thoothukudi, south-east coast of India. Indian Journal of Fisheries. 61: 60-67.

Wang, S., Jin, B., Qin, H., Sheng, Q. and Wu, J. (2015). Trophic dynamics of filter feeding bivalves in the Yangtze estuarine intertidal marsh: Stable isotope and fatty acid analyses. PloS one. 10: 0135604.

Ward, J.E. and Shumway, S.E. (2004). Separating the grain from the chaff: particle selection in suspension-and deposit-feeding bivalves. Journal of Experimental Marine Biology and Ecology. 300: 83-130.
Wijsman, J.W.M., Troost, K., Fang, J. and Roncarati, A. (2019). Global production of marine bivalves. Trends and challenges. In Goods and services of marine bivalves. Springer, Cham. pp. 7-26.

Xu, Q. and Yang, H. (2007). Food sources of three bivalves living in two habitats of Jiaozhou Bay (Qingdao, China): indicated by lipid biomarkers and stable isotope analysis. Journal of Shellfish Research. 26: 561-567.

Zuykov, M., Pelletier, E. and Harper, D.A. (2013). Bivalve Mollusks in metal pollution studies: From bioaccumulation to biomonitoring. Chemosphere. 93: 201-208. 